PIOTR CHOMCZYŃSKI

Uniwersytet Łódzki

\title{
FOTOGRAFIA W BADANIACH NAD STYGMĄ SPOŁECZNĄ. WNIOSKI METODOLOGICZNE Z BADAŃ NAD STYGMATYZACJĄ OSÓB, KTÓRE POPEŁNIŁY PRZESTĘPSTWO
}

AвSTRAct. Chomczyński Piotr, Fotografia w badaniach nad stygma społeczna. Wnioski metodologiczne z badań nad stygmatyzacja osób, które popetnity przestępstwo [Photography in Social Stigma Research. Some Methodological Conclusions from Research on Criminals' Stigmatization]. Studia Edukacyjne nr 44, 2017, Poznań 2017, pp. 177-194. Adam Mickiewicz University Press. ISSN 1233-6688. DOI: 10.14746/ se.2017.44.11

The goal of this paper is to present some preliminary methodological conclusions from research on social stigmatization of people who served time in prisons. It mainly discusses some patterns that underlie the process of photography interpretation made by interviewees within the techniques of in-depth interview and focus group interview. To characterize the research tools, contexts and circumstances of research are indicated which are important for the understanding of the outcomes obtained. The results are based on an analysis of forty in-depth interviews and eight focus group interview sessions. As this article is methodological in character, the problem of stigmatization as a subject of social research is only indicated as a context of the analyses presented in this paper.

Key words: stigma, stigmatization, labeling, qualitative methods, in-depth interview, focus group interview, visual sociology

\section{Wstęp}

Badania nad piętnem społecznym wymagają wiele wysiłku i zaangażowania ze strony badacza. Specyfika piętna jako przedmiotu badań wymaga podjęcia wielu działań, których wspólnym celem jest niejako „przedarcie się” przez deklaratywny poziom odpowiedzi osób badanych, dla których sam przedmiot badań wydaje się niejednokrotnie trudny, kłopotliwy, zawstydzający itd. Badani z różnych powodów, które przedstawię bliżej w dalszej części 
artykułu, wyrażają dyskomfort, a ten z kolei przekłada się zarówno na szczerość udzielanych odpowiedzi, lecz także na ich spójność i to jak informacje w nich zawarte są wyczerpujące. Brak motywacji po stronie badanych, lecz także czasami wstyd wynikający z konieczności dzielenia się z badaczem wypracowanymi przez siebie stereotypami i uprzedzeniami, spowodował konieczność zastanowienia się nad metodologią badań i podjęcia dodatkowych działań mających na celu pozyskanie akceptowalnego jakościowo materiału empirycznego. W tym celu zdecydowałem się wykorzystać fotografie, zarówno podczas indywidualnych wywiadów pogłębionych, jak również zogniskowanych wywiadów grupowych ${ }^{1}$. Wnioski zawarte $\mathrm{w}$ niniejszym artykule mają charakter studiów nad metodą badań.

Należy także zaznaczyć, że z reguły badania nad społecznym piętnem odnoszą się do dwóch aspektów niniejszego zjawiska: koncentracji na osobach, które stygmatyzują oraz na osobach poddawanych stygmatyzacji. W tym przypadku chciałbym podjąć się omówienia metodologii prowadzenia badań obejmujących pierwszą grupę. Zanim jednak przejdę do zasadniczej części pracy, pozwolę sobie najpierw przybliżyć w kilku słowach samo pojęcie stygmy społecznej, dewiacji i związanych z tymi zagadnieniami teorii etykietowania.

\section{Pojęcie stygmy, dewiacji oraz teorie etykietowania}

O tym, że oceniamy i na tej podstawie podejmujemy określone działania lub je wygaszamy nie trzeba już chyba nikogo przekonywać, gdyż literatura naukowa z zakresu psychologii, psychologii społecznej, pedagogiki czy socjologii ${ }^{2}$ na tyle obfituje w przykłady eksperymentów i obserwacji, że twierdzenie to nabiera cech tautologii. Bazując na pierwszym wrażeniu, oceniamy innych już po kilku sekundach i nie jesteśmy szczególnie skłonni do zmiany

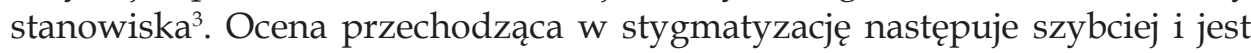
bardziej intensywna, kiedy bezpieczeństwo nasze i innych zależy od właściwego rozpoznania sytuacji, a czasu na wnikliwą obserwację jest niewiele.

Za pioniera badań nad piętnem społecznym uważa się Ervinga Goffmana, który jako pierwszy, w sposób uporządkowany, poruszył problem społecznej izolacji osób stygmatyzowanych. W książce zatytułowanej Piętno

\footnotetext{
${ }^{1}$ Pragnę podziękować studentom I roku zaocznych studiów II stopnia na kierunku socjologii, którzy pomogli mi zarówno w kwestii organizacji badań, a także w ich przeprowadzeniu. Ponadto, dziękuję także Panu prof. Krzysztofowi T. Koneckiemu i Pani dr Jolancie Lisek-Michalskiej za konsultacje dotyczące badań.

${ }^{2}$ Por. E. Aronson, R.M. Akert, T.D. Wilson, Psychologia społeczna, przekł. Joanna Gilewicz, Warszawa 2012; R. Cialdini, Wywieranie wptywu na ludzi. Teoria i praktyka, Gdańsk 2009.

${ }^{3}$ Por. B. Gawroński i in., Generalization Versus Contextualization in Automatic Evaluation, Journal of Experimental Psychology: General Advance online publication, 2010 (October 4).
} 
(tytuł oryginalny Stigma ${ }^{4}$ ) zastanawia się nad funkcjonowaniem osób, które ze względu na pewne własne atrybuty (a raczej ich społeczną interpretację) zepchnięte są na margines życia społecznego. Samo piętno ${ }^{5}$ charakteryzuje on w kategoriach "sytuacji jednostki pozbawionej pełnej społecznej akceptacji” ${ }^{6}$. Stygmatyk to osoba uważana ze względu na swoje atrybuty za kogoś niepełnowartościowego ${ }^{7}$, kto nie cieszy się pełnią praw, a jego partycypacja w życiu społecznym jest warunkowa. Stygmatyków, czyli osoby noszące piętno, dzieli na dwie podstawowe kategorie: osoby zdyskredytowane, czyli podlegające społecznej marginalizacji ze względu na defekty widoczne na pierwszy rzut oka oraz osoby dyskredytowalne, których tajemnicę można odkryć jedynie przy okazji ich głębszego poznania. W przypadku badań nad społeczną stygmą osób, które odsiadywały karę pozbawienia wolności, jestem zainteresowany drugą z wymienionych kategorii stygmatyków. Warto także nadmienić o społecznej naturze piętna, gdyż to ona, ze względu na cele badawcze obrane w pracy, jest tutaj najważniejsza. Piętno w ujęciu goffmanowskim opiera się nie tyle na cechach jednostki, co na ich interpretacji, jaką dokonuje otoczenie ${ }^{8}$. Piętno zatem, w myśl założeń Goffmana, zależy nie tyle od obiektywnie wyodrębnionych atrybutów, jakie posiada jednostka, lecz od ich społecznej interpretacji, choć z drugiej strony ludzie mogą także wobec siebie samych stosować praktyki autostygmatyzacyjne (np. tatuaże, sposób mówienia, poruszania się itp.), które inicjują społeczną stygmatyzację. Przykładem mogą być wychowankowie instytucji korekcyjnych dla nieletnich ${ }^{9}$.

Pisząc o stygmatyzacji oraz teorii etykietowania, należy wspomnieć o wkładzie Edwina M. Lemerta, którego książka Social Pathology: A Systematic Approach to the Theory of Sociopathic Behavior wywarła fundamentalny wpływ na sposób myślenia o piętnie społecznym i naznaczaniu. Dla Lemerta istnieje silny związek pomiędzy społecznym potępianiem danego zachowania a kontekstem czasowym i sytuacyjnym jego wystąpienia. U podstaw społecznego definiowania dewiacji leży kontekst kulturowy, w jakim dane zachowanie się pojawia ${ }^{10}$. Lemert zwrócił także uwagę na społeczne nadawanie statusu

${ }^{4} \mathrm{~W}$ artykule będę zamiennie stosował pojęcia piętno i stygmat, z których to ostatnie jest polskim odpowiednikiem angielskiego słowa stigma.

${ }^{5}$ E. Goffman rozróżnia trzy rodzaje piętna (defekt fizyczny, cechy charakteru i osobowości oraz piętno grupowe), których nie będę w niniejszym artykule charakteryzować.

${ }^{6}$ E. Goffman, Piętno, przekł. A. Dzierżyńska, J. Tokarska-Bakir, Gdańsk 2005, s. 27.

${ }^{7}$ Tamże, s. 32.

${ }^{8}$ Por. J. Pawłowska, Pojęcie dewiacji w teorii etykietowania, Studia Socjologiczne, 1985, 1(96), s. 37.

${ }^{9}$ Por. P. Chomczyński, Problem etykietowania i stygmatyzacji wśród wychowanków zakładów poprawczych $i$ schronisk dla nieletnich. Socjologiczna analiza zjawiska, Studia Socjologiczne, 2015, 4(219).

${ }^{10}$ Por. Z. Welcz, Powstanie i rozwój teorii naznaczania społecznego, Studia Socjologiczne, 1985, 1(96), s. 69. 
dewianta osobie, która dopuściła się czynu uważanego przez innych za dewiacyjny. Na podstawie tych wniosków formułuje teorię wtórnej dewiacji (Theory of Secondary Deviance). Według jej założen, sprawca na podstawie społecznej oceny swego czynu zaczyna podejmować rolę dewianta, tym samym potwierdzając trafność wcześniej nadanego mu statusu.

Lemert w swej koncepcji przyjmuje założenia Cooleya odnośnie jaźni odzwierciedlonej, która w tym przypadku wyznacza scenariusz postępowania osoby społecznie definiowanej jako dewiant. W myśl założeń Lemerta, to otoczenie swą reakcją współwyznacza trajektorię (dewiacyjną karierę) osoby nabywającej status dewianta ${ }^{11}$.

Znaczący wkład w rozwój teorii etykietowania stał się także, jak już wcześniej wspomniałem, udziałem Howarda Beckera za sprawą jego głośnej książki Outsiders. Studies in the Sociology of Deviance. Becker wykorzystuje założenia symbolicznego interakcjonizmu wiążąc je $\mathrm{z}$ teorią etykietowania dla opisania dewiacji ${ }^{12}$. Zachowanie jednostki jest, jego zdaniem, wtedy dewiacyjne, gdy ludzie nadają mu taką etykietę ${ }^{13}$. Dewiacja jest wytworzona społecznie przez otoczenie, w jakim znajduje się jednostka. Tym samym zdecydowanie odrzuca przekonanie, że dewiantem jest osoba, która ma w sobie jakiś element różniący ją od innych, a który to popycha ją do społecznie potępianych czynów ${ }^{14}$.

Przy tej okazji warto w paru zdaniach przybliżyć założenia Roberta Prusa i Scotta Grillsa odnośnie zjawiska dewiacji w kontekście jej społecznego kreowania. Choć Autorzy jawnie tego nie deklarują, to pozostają bardzo blisko założeń teorii etykietowania. W książce Deviant Mystique prezentują proces społecznego definiowania jednostek jako dewiantów, stosując perspektywę interakcyjną. Podejmują próbę demistyfikacji zjawisk dewiacyjnych poprzez ukazanie problemu infamii społecznej osób dewiacyjnych. Prus i Scott wskazują na społeczne uwarunkowania wytwarzania dewiacji. W polu uwagi Prusa i Grillsa znajduje się zagadnienie społecznego definiowania jednostki przez grupę jako osoby dewiacyjnej, a także kwestia doświadczania statusu dewianta oraz społecznych regulacji odnośnie kontaktów z dewiantem. Zdaniem autorów, dewiacja rodzi się na poziomie definiowania przez grupę sytuacji i określonej osoby jako dewiacyjnej. Oznacza to, że w ujęciu Prusa i Grillsa, podobnie jak Orrin Klapp (1956), na pierwszym planie nie znajdują się posiadane przez jednostkę atrybuty,

${ }^{11}$ Zbigniew Welcz mówi o teorii reakcji społecznej, która głosi, że istotne dla zaistnienia dewiacji jest "naznaczenie” zachowania lub czynu - nazwanie go „dewiacją".

${ }^{12}$ Zob. Z. Bokszański, Tożsamość, interakcja, grupa. Tożsamość jednostki w perspektywie teorii socjologicznej, Łódź 1989, s. 177-178.

${ }^{13}$ Por. J. Pawłowska, Pojęcie dewiacji, s. 42.

${ }^{14}$ Z. Bokszański, Tożsamość, interakcja, grupa, s. 178. 
bądź czyny przez nią popełniane, lecz to, w jaki sposób są one definiowane przez otoczenie, które przypisuje im określone znaczenie. Dewiantem jest się w mniemaniu czyimś lub grupy osób.

O samej dewiacji można mówić, zdaniem Prusa i Grillsa, jako o procesie społecznym, gdyż dewiacja jest konstrukcją społeczną (social construction of deviance) trwającą w czasie. Autorzy zwracają także uwagę na społeczny kontekst definiowania dewiacji, który obejmuje środowiska opiniotwórcze. Reprezentanci tych środowisk nakreślają i definiują problem dewiacji aktywnie uczestnicząc w budowaniu społecznych postaw wobec niej. Dostarczają także języka opisu dewiacji oraz wyczulają odbiorców swych przekazów na problem zachowań dewiacyjnych. Wśród nich znajdują się zarówno media, politycy, naukowcy, jak i Kościół.

W tym momencie rodzi się pytanie odnośnie związku logicznego pomiędzy dewiacją a stygmą społeczną. W literaturze przedmiotu niniejsza relacja nie jest opisana, zaś obydwa zagadnienia są z reguły opisywane osobno lub wymiennie. $W$ moim przekonaniu można przyjąć, że konsekwencją dewiacji jest stygmatyzacja, choć oczywiście nie jest to relacja bezwyjątkowa, gdyż praktykom stygmatyzacyjnym mogą być poddawane także osoby, które nie są dewiantami, jak choćby osoby z widocznymi defektami fizycznymi opisywane przez Goffmana. Z drugiej także strony, nie wszyscy dewianci podlegają społecznej stygmatyzacji. W moim przekonaniu warto jednak wskazać na niniejszą relację pomiędzy dewiacją i stygmatyzacją, gdyż okazuje się ona pomocna w większości przypadków wchodzących w skład desygnatów tych nazw.

\section{Fotografia w wywiadach jakościowych}

Zainteresowanie wykorzystaniem materiałów wizualnych w socjologii staje się coraz bardziej widoczne, czego namacalnym dowodem jest upowszechnienie się samej nazwy socjologia wizualna. Badacze społeczni częściej niż kiedyś sięgają do materiałów wizualnych, upatrując w nich szansę na zbadanie tych aspektów rzeczywistości, które do tej pory pozostawały na marginesie zainteresowań badawczych lub ich eksploracja była utrudniona. Wspomnieć można choćby o badaniach wykonanych przez Iris Epstein, Bonnie Stevens ${ }^{15}$ (2006), w których fotografie wykorzystano z powodzeniem do przeprowadzenia wywiadów z dziećmi, a także Brendę Robertson (bez daty), która za pomocą fotografii badała sposoby spędzania wolnego czasu przez młodzież, czy też badania Krzysztofa T. Koneckiego (2005a) dotyczące społecznego świata właścicieli zwierząt domowych.

\footnotetext{
${ }^{15}$ Oraz zespół.
} 
W niniejszym artykule chciałbym skupić się jedynie na niewielkim fragmencie tych wszystkich zagadnień, które kryją się pod pojęciem socjologii wizualnej, a mianowicie na wykorzystaniu fotografii $w$ indywidualnych wywiadach pogłębionych oraz zogniskowanych wywiadach grupowych ${ }^{16}$. Pomysł wykorzystania zdjęć w wywiadach nie do końca wpisuje się $\mathrm{w}$ klasyfikację strategii badawczych z użyciem fotografii. Zaprezentowane przeze mnie wnioski najbliższe są jednemu z podejść, mianowicie użyciu fotografii jako materiałów zastanych powiązanych z materiałami wywołanymi, to jest z narracjami i komentarzami werbalnymi dokonanymi przez respondentów odnośnie pokazywanych im zdjęć ${ }^{17}$. Technika ta nosi nazwę wywiadu z użyciem fotografii (photo elicitation interview ${ }^{18}$ - PEI) i opiera się na połączeniu spontanicznie uzyskiwanych informacji z informacjami wynikającymi z zadawanych pytań ${ }^{19}$. W tym miejscu należy podkreślić, że różnicę stanowi fakt, iż wykonaniu fotografii nie tylko nie towarzyszyła intencja wykorzystania ich w badaniach, lecz także nie zostały one wykonane tak przez badanych, jak i badacza i nie są z nimi w żaden sposób powiązane. Należy także zaznaczyć, że celem wykorzystania zdjęć w sytuacji badawczej z udziałem badanych jest sprowokowanie ich do udzielania spontanicznych wypowiedzi opartych na wcześniej nie widzianych obrazach, nie zaś analiza socjologicznego kontekstu towarzyszącego robieniu zdjęć zazwyczaj towarzysząca badaniom wizualnym ${ }^{20}$. W tym przypadku kompletowanie fotografii było dokonywane w ramach źródeł niepowiązanych w żaden sposób z badanymi, a jedynie z uwzględnieniem założeń teoretycznych i metodologicznych, na których bazował niniejszy projekt badawczy.

\section{Zdjęcia w badaniach nad społeczną stygmą}

Jak podają źródła literaturowe, istnieje zasadnicza zgoda co do faktu, że piętno ma rodowód społeczny, gdyż jest wytwarzane w toku interakcji grupowych. U jego podstaw leżą działania wynikające ze społecznych interak-

${ }^{16}$ Wnioski przedstawione $\mathrm{w}$ niniejszym artykule oparto na czterdziestu wywiadach pogłębionych i ośmiu sesjach fokusowych. Por. P. Daniłowicz, J. Lisek-Michalska, Fokus - zogniskowany wywiad grupowy. Zarys metody, [w:] Zogniskowany wywiad grupowy. Studia nad metoda, red. J. Lisek-Michalska, P. Daniłowicz, Łódź 2004; J. Lisek-Michalska, Badania fokusowe. Problemy metodologiczne i etyczne, Łódź 2013.

${ }^{17}$ K.T. Konecki, Ludzie i ich zwierzęta. Interakcjonistyczno-symboliczna analiza społecznego świata wtaścicieli zwierząt domowych, Warszawa 2005, s. 44.

${ }^{18} \mathrm{~W}$ literaturze przedmiotu spotkać można także nazwę photo elicited interview.

${ }^{19}$ M. Frąckowiak, Zdjęcie jako rebus. Zastosowanie wywiadu fotograficznego na przykładzie badań „Pornografia/erotyka: pytanie o kontekst czy estetyke??" [w:] Do zobaczenia. Socjologia wizualna w praktyce badawczej, red. J. Kaczmarek, Poznań 2008, s. 42.

${ }^{20}$ P. Sztompka, Socjologia wizualna. Fotografia jako metoda badawcza, Warszawa 2005. 
cji, w ramach których dochodzi do konstruowania stereotypów, opinii, obaw itp., leżących u podstaw praktyk stygmatyzacyjnych. Stanowiska aktorów społecznych są artykułowane na skutek uzgodnień i negocjacji wyrastających $\mathrm{z}$ ich wzajemnych interakcji. W naszym sposobie postrzegania świata znaczną rolę odgrywa także obraz. Obrazami posługujemy się w budowaniu i propagowaniu przyjmowanych przez nas definicji sytuacji. Wygląd fizyczny człowieka odgrywa ważną rolę w jego społecznym odbiorze. Nowo poznana osoba już w przeciągu kilku sekund wywołuje na nas określone wrażenie, którym kierujemy się w relacjach z nią. Liczy się wygląd fizyczny, ubiór oraz inne artefakty służące identyfikacji jednostki i tworzenia jej klasyfikacji mentalnej ${ }^{21}$. Ze względu na temat pracy, jakim jest stygmatyzacja osób, które odsiadywały karę pozbawienia wolności, analiza zdjęć wydaje się naturalnym i pomocnym narzędziem służącym eksploracji niniejszego zagadnienia. Jak postaram się udowodnić, fotografie okazały się niezbędne $\mathrm{w}$ analizie zjawisk leżących u podstaw społecznej stygmy ${ }^{22}$. Zanim jednak przejdę do wniosków, w kilku zdaniach opiszę inne czynniki, które wsparły moją decyzję o wykorzystaniu fotografii $w$ badaniach.

Pomysł wykorzystania zdjęć w wywiadach pogłębionych wynikał także z faktu przeprowadzenia kilkunastu wywiadów w sposób tradycyjny, czyli na podstawie standardowo zadawanych pytań z listy. Wśród problemów, jakie pojawiły się podczas wywiadów można wymienić:

1) Trudności w werbalizacji opinii, uprzedzeń, stereotypów odnośnie osób, które posiadaja kryminalna przeszłość. Badani niejednokrotnie uznawali, że nie mają zdania odnośnie pytań związanych z ich odczuciami wobec osób karanych. W przypadku pytań bezpośrednio związanych z uprzedzeniami o podłożu fizjonomicznym uczestnicy deklarowali niemożność wyrażenia opinii, zasłaniając się brakiem wcześniejszej refleksji na ten temat lub trudnością w przypomnieniu sobie odpowiedzi.

2) Część badanych deklarowata brak związu pomiędzy fizjonomia człowieka a jego przestępczymi skłonnościami. W rezultacie niniejszych stwierdzeńn ${ }^{23}$ dalsza dyskusja na ten temat stawała się bezprzedmiotowa, gdyż badani konsekwentnie odmawiali udziału $\mathrm{w}$ badaniu lub uzyskiwane od nich informacje nie pozwalały na kontynuacje badań.

${ }^{21}$ Zob. R. Cialdini, Wywieranie wptywu na ludzi; E. Aronson, R.M. Akert, T.D. Wilson, Psychologia społeczna.

${ }_{22}$ Por. K.T. Konecki, Wizualna Teoria Ugruntowana. Nauczanie teorii ugruntowanej przy pomocy obrazów i analizy wizualnej, Przegląd Socjologii Jakościowej, 2010, VI, 2, s. 3, pobrany: czerwiec 2011, (http://www.qualitativesociologyreview.org /PL/archive_pl.php).

${ }^{23}$ Stwierdzenia te są elementem pewnej nieformalnej i nie wyrażanej wprost umowy społecznej, która zakłada nieocenianie ludzi ze względu na wygląd. W moim przekonaniu badani odmawiając wypowiedzi na ten temat lub dostarczając wypowiedzi zdawkowych, prezentowali zakres i siłę oddziaływania tej umowy. 
3) Niektórzy badani stwierdzali, że werbalizując swoje prywatne opinie postępuja w sposób krzywdzący wobec osób, które posiadając wymienione przez nich atrybuty fizyczne, mogą okazać się niewinne. Część osób odczuwała dyskomfort wynikający z faktu, że są postawieni w roli sędziego, który powierzchownie kierując się jedynie atrybutami fizycznymi, przypisuje komuś określone predyspozycje behawioralne. Niektóre osoby uznawały pytania za infantylne i/lub wprowadzające w błąd.

4) Częśc osób bioracych udziat w wywiadach wyrażata obawe, że ich biegłość w prezentowaniu własnych opinii odnośnie osób z przeszłością kryminalna może narazić ich samych, w oczach badacza, na podejrzenie o posiadanie znajomości z kryminalistami. Niniejsze obawy utwierdziły mnie w przekonaniu, że problem społecznej stygmy osób odsiadujących karę pozbawienia wolności należy do sfery tabu i nie zawsze sprawdzają się tradycyjne techniki pozyskiwania danych oparte na tradycyjnym zadawaniu pytań.

5) W części przypadków badani nie wyrażali zainteresowania badaniem, zaś poruszane przez badacza kwestie wydawaty się im zbyt abstrakcyjne. W konsekwencji udzielane odpowiedzi miały charakter ograniczony jedynie do zaprzeczeń lub potakiwań i były ukierunkowane na jak najszybsze zakończenie badań.

W konsekwencji wyżej opisanych trudności, zdecydowałem się wykorzystać fotografie zarówno w ramach techniki wywiadów swobodnych, jak również zogniskowanych wywiadów grupowych. Za tym pomysłem przemawiało kilka ważnych argumentów podnoszonych przez badaczy, którzy stosują zdjęcia w wywiadach jakościowych. Wśród nich można wymienić:

- Zdaniem Douglasa Harpera zdjęcia pobudzają aktywność innych partii mózgu niż w przypadku operowania jedynie słowami, w związku z czym pojawia się możliwość uzyskania pełniejszego zakresu poszukiwanych informacji ${ }^{24}$;

- Dyskusja nad fotografią zwiększa równowagę władzy (balance of power) pomiędzy badaczem i badanym ${ }^{25}$, co sprawia, że relacja ma charakter partnerski i bardziej zbliżony do warunków towarzyszących naturalnej rozmowie, niż typowych dla standardowego wywiadu;

${ }^{24}$ Por. D. Harper, Talking about pictures: a case for photo elicitation, Visual Studies, 2002, 17, 1, s. 13.

${ }^{25}$ Oczywiście, argumentów na rzecz wykorzystywania fotografii w badaniach jest znacznie więcej, jednakże ja wybrałem jedynie te, które w sposób najbardziej bezpośredni wiążą się ze specyfiką niniejszego projektu badawczego. Por. B.J. Robertson (bez daty), Photo Elicitation: a window through which to view youth leisure in isolated communities, http://lin.ca/ Uploads/cclr11/CCLR11-124.pdf, [dostęp: 30.09.2009]; Ch.A. Le Dantec, E.S. Poole, The Value of Pictures: Photo Elicitation Techniques for Value Sensitive Techniques, Florence, Italy 2008, s. 2, http:/ / www.cc.gatech.edu/ ledantec/files/ledantec-poole-valueofpics-chi08.pdf, [dostęp: 30.09.2009]. 
- Zdjęcia wykorzystane $\mathrm{w}$ wywiadach pogłębionych prowokują rozmówcę do swobodnego wyrażania opinii i komentowania omawianych za$\operatorname{gadnieńn}^{26}$.

Niniejsze argumenty ${ }^{27}$, związane zarówno z dotychczas przeprowadzonymi badaniami jak również z literaturą przedmiotu, wskazywały na zasadność wykorzystania materiału wizualnego. Zanim przejdę do analizy wniosków metodologicznych odnośnie obydwu technik badawczych, w których fotografie znalazły zastosowanie, wcześniej omówię chronologię działań badawczych, ważną z punktu widzenia metodologii badań i celów niniejszego artykułu.

\section{Organizacja badań}

Jak już wspomniałem, główną intencją wykorzystania fotografii w badaniach było "przedarcie się" przez powierzchowne (deklaratywne) i nie do końca szczere opinie artykułowane przez badanych. Dysponując już pewnym doświadczeniem w prowadzeniu wywiadów jakościowych, obserwowałem wśród badanych reakcje, które w moim przekonaniu świadczyły na rzecz stanowiska, że nie są oni ze mną do końca szczerzy w swoich odpowiedziach. Pytania dotyczące ich percepcji byłych kryminalistów okazały się, jak już wspomniałem, w dużej mierze osadzone w społecznym tabu. Badani niejednokrotnie wyraźnie eksponowali uczucie wstydu, zniecierpliwienia, bądź deklarowali brak wiedzy itp., choć jednocześnie miałem wrażenie, iż rzeczywistą przyczyną braku werbalizacji własnych opinii jest uczucie dyskomfortu wynikającego $\mathrm{z}$ ich uczestnictwa w sytuacji dla nich trudnej. Po przeanalizowaniu celów badawczych oraz zestawieniu ich z dotychczas otrzymanymi wynikami, zdecydowałem się na wykorzystanie zdjęć najpierw $\mathrm{w}$ przypadku indywidualnych wywiadów pogłębionych, potem zaś zogniskowanych wywiadów grupowych. W tym celu zdecydowałem się na wybór trzydziestu zdjęć, którym narzuciłem określone kryteria:

- osoba przedstawiona na zdjęciu nie mogła być osobą publiczną, czyli w jakikolwiek inny sposób rozpoznawalną;

- zdjęcie nie mogło sprawiać wrażenia efektu profesjonalnej sesji fotograficznej, zaś osoba na nim umieszczona nie mogła być kojarzona z zawodową

${ }^{26}$ I. Epstein i in., Photo elicitation interview (PEI): Using photos to elicit children's perspectives, International Journal of Qualitative Methods, 2006, 5(3), Article 1, s. 3, [Retrieved: 26.09.2015] from http://www.ualberta.ca/ iiqm/backissues/5_3/pdf/ epstein.pdf.

${ }^{27}$ Zmniejszenie dystansu jest przypisywane głównie wywiadom, gdzie sami badani robią zdjęcia, które są następnie omawiane wraz z badaczem. Z mojego doświadczenia wynika jednak, że obniżenie dystansu pomiędzy badaczem i badanym towarzyszy także w przypadku wspólnego omawiania zdjęć jako źródeł zastanych. 
modelką/modelem lub inną osobą czerpiącą zysk z publikacji swojego wizerunku;

- na zdjęciach mogły widnieć jedynie osoby dorosłe;

- wybierając zdjęcia starałem się kierować zasadą reprezentacji osób w różnym wieku oraz różnej płci ${ }^{28}$;

- starałem się unikać zdjęć zdecydowanie sugerujących odpowiedzi poprzez atrybuty skłaniające do natychmiastowej stygmatyzacji (np. osoby trzymające groźne narzędzia, w otoczeniu więziennym i/lub więziennym ubiorze, posiadające tatuaże, skaryfikacje ciała itd.).

Wybrane $\mathrm{w}$ ten sposób zdjęcia przedyskutowałem ze studentami biorącymi udział w projekcie. Wspólnie dokonaliśmy dalszej selekcji zdjęć. Po skompletowaniu ostatecznego zestawu fotografii spełniających wyżej opisane kryteria, zdecydowaliśmy się zarówno w przypadku badań opartych na technice wywiadu swobodnego, jak również wywiadu grupowego, pokazać badanym zdjęcia. Rozmówcy zostali poinformowani, że wśród osób przedstawionych na fotografiach znajdują się oprócz „zwykłych ludzi” także byli kryminaliści, którzy odsiadywali karę pozbawienia wolności, bez ujawniania ich procentowego udziału. Uczestnicy badania zostali poproszeni o wytypowanie osób, które ich zdaniem popełniły przestępstwa, a następnie udzielenie odpowiedzi o jaki rodzaj przestępstwa chodzi. Ze względu na fakt, że część badanych z powodu braku wiedzy odnośnie klasyfikacji przestępstw doświadczała trudności w artykulacji rodzaju przestępstwa, w dalszej części badań opartych na technice wywiadu grupowego, zdecydowałem się na ułożenie listy przestępstw, poczynając od najmniej groźnych do najbardziej poważnych. Każdy rodzaj przestępstwa został dodatkowo opatrzony krótkim opisem, pozwalającym na udzielenie możliwie najbardziej jednoznacznej odpowiedzi. Celem zachowania maksymalnie znośnej standaryzacji, zarówno w przypadku wywiadów pogłębionych jak i zogniskowanych grupowych, wykorzystano te same zestawy zdjęć, jak również polecenia skierowane wobec badanych miały taką samą treść.

\section{Zdjęcia w wywiadach pogłębionych i zogniskowanych grupowych}

Pomimo wcześniej opisanych zabiegów standaryzujących (identyczne polecenia wobec badanych, te same zestawy zdjęć oraz opisy przestępstw),

${ }^{28}$ Padł także pomysł doboru fotografii przedstawiających przedstawicieli innych nacji, celem zbadania stereotypów związanych z rasą. Ze względu na ograniczony czas postanowiłem pomysł ten zrealizować przy innej okazji. 
ze względu na odmienną specyfikę obydwu technik badawczych, zdecydowałem się na omówienie osobno roli, jaką odegrały zdjęcia w każdej z nich.

Zdjęcia $w$ wywiadach pogłębionych. Ze względu na fakt, że $\mathrm{w}$ tym samym badaniu, $\mathrm{w}$ niewielkim przedziale czasowym, zastosowano jednocześnie „tradycyjny" wywiad pogłębiony, to jest bez użycia fotografii oraz kilka tygodni później wywiad pogłębiony wzbogacony o część wizualną, istnieje możliwość dokonania $w$ miarę rzetelnych porównań odnośnie rezultatów wprowadzenia analizy zdjęć do wywiadu. Zestawienie takie daje możliwość prześledzenia metodologicznych aspektów zastosowania fotografii w niniejszych badaniach. Oczywiście, omówione zostaną jedynie te wnioski, które udało się wyraźnie dostrzec, jednak należy mieć świadomość, że być może nie wyczerpują one $\mathrm{w}$ pełni omawianego zagadnienia. $\mathrm{Z}$ moich obserwacji, rozmów z respondentami po wywiadach, jak również uwag studentów biorących udział w projekcie, wynika, że:

1) Zdjęcia dają możliwość zbudowania atmosfery otwartości w relacjach badacz-badany w sposób bardziej efektywny niż w przypadku tradycyjnego wywiadu pogłębionego. Kontakt pomiędzy badaczem i badanym jest zapośredniczony przez fotografie, które egalitaryzują obydwie role do postaci bardziej partnerskiej. Fotografie wprowadzają element dyskusji, który przeformułowuje sytuację, w której, jak zaznacza Anna Wyka ${ }^{29}$, jedna osoba rezerwuje dla siebie prawo do zadawania pytań (pozycja wyższa), zaś drugiej pozostaje udzielanie odpowiedzi (pozycja niższa). Ponadto, wspólna dyskusja, której kanwę stanowią zdjęcia, zbliża rozmowę do postaci typowego spotkania towarzyskiego, niejednokrotnie stającego się okazją do robienia i/bądź pokazywania zdjęć. Konstruowanie atmosfery otwartości także jest swoistym „narzędziem”, które wydaje się szczególnie ważne w przypadku badań zjawisk uznawanych przez ludzi jako trudnych, kłopotliwych, wywołujących uczucie dyskomfortu, leżących w sferze tabu.

2) Zdjęcia prowokuja badanych do poruszania tematów abstrakcyjnych zwiąanych z ich odczuciami, fobiami, stereotypami itd. Fotografie dostarczają badanym pretekstu do głębszej analizy własnych opinii odnośnie związku pomiędzy fizjonomią człowieka a skojarzeniami wiązanymi z jego domniemanym postępowaniem. Rozmowy na ten temat opierają się na cechach wyglądu, które czasami trudno wywołać z pamięci niewspomaganej obrazem. Obraz w tym przypadku stanowi punkt odniesienia dla inicjowania i ekspresji wizualnych doświadczeń badanych. Aby uzyskać dodatkowe, cenne dla mnie informacje, badani byli proszeni o uargumentowanie swoich odpowiedzi. Niejednokrotnie osoby biorące udział w badaniu powoływały się na obrazy popularyzo-

${ }^{29}$ A. Wyka, Badacz społeczny wobec doświadczenia, Warszawa 1993, s. 24-25. 
wane przez środki masowego przekazu (filmy fabularne ${ }^{30} \mathrm{i}$ dokumentalne, treści zawarte $\mathrm{w}$ serwisach informacyjnych, artykuły gazetowe itp.). Może to rodzić zasadne przypuszczenia o dużej roli niniejszych przekaźników w kształtowaniu opinii badanych na temat osób z przeszłością kryminalną.

3) Prezentowanie badanym arbitralnie wyselekcjonowanych zdjęć dzieli odpowiedzialność "niesprawiedliwego" osadu pomiędzy badacza i badanego. Badani wielokrotnie deklarowali w przypadku wywiadów "tradycyjnych", że nie istnieje związek pomiędzy fizjonomią człowieka a jego postępowaniem, zaś próby szukania powiązań są niesprawiedliwe i nieetyczne. W przypadku wywiadów wzbogaconych o analizę wizualną, fakt wyboru przez badacza zdjęć sprawił, że badani uważali, iż ciężar odpowiedzialności za "pomyłkę" w typowaniu „niewinnego" człowieka jako przestępcy jest rozłożony pomiędzy nich a badacza. W rezultacie skłonni byli artykułować opinie, które w innym przypadku zachowaliby jedynie dla siebie.

4) Zdjęcia budza ciekawość $i$ sprawiaja, że samo badanie wydaje się osobom bioracym w nim udział bardziej interesujące, w zwiazku z czym czuja się bardziej odpowiedzialni za jego przebieg. Analiza fotografii uatrakcyjnia przebieg badania, co w rezultacie przekłada się także na jakość uzyskiwanych danych. Badani $\mathrm{w}$ większym stopniu angażują się $\mathrm{w}$ udzielanie pełniejszych i bardziej wyczerpujących odpowiedzi, niekiedy posiłkując się wartościowymi dla celów badawczych anegdotami lub porównaniami.

5) Wtaczenie zdjęć w proces badawczy daje możliwość uzyskania bardziej petnego zakresu danych niż jedynie opartych na tradycyjnym wywiadzie pogłebionym. Połączenie elementów wizualnych i werbalnych daje efekt synergii pozytywnej, gdyż uzyskiwane $\mathrm{w}$ ten sposób informacje wykraczają poza dane, które byłyby pozyskane osobno. Rodzi to uzasadnione przypuszczenie o pozytywnych skutkach cytowanych słów Harpera odnośnie efektów pobudzania różnych partii mózgu odpowiadających za analizę materiałów wizualnych i werbalnych.

6) Dobór zdjęć wymaga uwagi i staranności, gdyż może w sposób niekontrolowany wptynać na charakter uzyskiwanych odpowiedzi. W tym przypadku trudność polegała na tym, by sam format zdjęcia lub/i inne aspekty związane ze zdjęciem, a jednocześnie nie będące przedmiotem badań, nie rzutowały na opinie głoszone przez badanych. Zdjęcia musiały być przygotowane w ten sposób, by nie budzić podejrzeń, że zarówno uzyskane przez badanego informacje, jak również sam charakter zadania nie są oparte na faktach.

7) W ramach studiów nad metoda zdjęcia pokazywane były na końcu wywiadu po zadaniu pytań z listy. Analiza wywiadów wskazała, że zdjęcia pokazane

${ }^{30}$ Badani w swoich opiniach powoływali się niejednokrotnie na wyświetlany w tym czasie przez telewizję, zyskujący dużą popularność, film fabularny „Skazany na śmierć”. 
na początku badania rzutują na odpowiedzi udzielane w dalszej części. Ze względu na temat badawczy i zagadnienia metodologiczne interesująca jest tutaj raczej dynamika wypowiedzi i ewentualna zmiana postaw badanych, co jest możliwe do uchwycenia jedynie przy spełnieniu powyższego warunku. Badani niejednokrotnie prezentowali powierzchowne i obiegowe opinie do momentu, kiedy eksponowane były im fotografie. $W$ dalszej części badania ujawniane poglądy znacznie zyskiwały na bogactwie $w$ detale odnoszące się do cech wizualnych opisywanych przez rozmówców osób. To z kolei pozwoliło na wysnucie wstępnych wniosków na temat roli fotografii w inicjowaniu i przebiegu wypowiedzi badanych. Moment przełomowy miał związek z wcześniej opisanymi przeze mnie aspektami.

8) Zdjęcia daja możliwość uzyskania danych wymykających się przewidywaniom. Analiza zdjęć pobudza badanych i redukuje wśród nich poczucie stresu, w związku z czym ujawniają oni informacje, które mogą stanowić zwrot $\mathrm{w}$ dotychczasowych przypuszczeniach odnośnie istoty analizowanego zjawiska. Badacz często nie jest w stanie przewidzieć, jakie czynniki, bądź ich wzajemne powiązania, mogą przesądzać o określonym postrzeganiu „przestępców”, u którego podstaw w dużej mierze leży to, co się widzi. Analiza zdjęć stanowi zatem odzwierciedlenie istoty badanego problemu, $w$ tym przypadku społecznej stygmatyzacji, opartej głównie na wrażeniach wzrokowych.

Zdjeccia w zogniskowanych wywiadach grupowych. W wywiadach tych badani zostali poproszeni o wypełnienie identycznego zadania z udziałem zdjęć, jak w przypadku wywiadów pogłębionych, inne były jednak okoliczności, przebieg oraz rezultaty procesu badawczego. Wynikały one z faktu, że uczestnicy działali $w$ grupie i byli poddani efektom grupowym ${ }^{31}$. Badani zadawali pytania sobie nawzajem, jak również moderatorowi, w związku z czym zaistniały warunki wspierające możliwość odtworzenia naturalnej sytuacji, w której ludzie w grupie negocjują i konstruują znaczenia. Oczywiście, należy mieć świadomość ograniczeń typowych dla narzędzia fokusowego, jak choćby prowadzenie dyskusji w warunkach laboratoryjnych, celowe i odgórne ograniczanie spontaniczności zachowań uczestników, narzucenie tematu spotkania itd..$^{32}$ Niniejsze słabości metody nie rzutują jednak na samą zasadność wyboru wywiadu grupowego niejednokrotnie wykorzystywanego w analizie zjawisk negatywnych i objętych tabu społecznym, jak choćby

${ }^{31}$ Zob. H. Malinowski, Komunikacja w zogniskowanym wywiadzie grupowym, [w:] Zogniskowany wywiad grupowy; J. Lisek-Michalska, Badania fokusowe.

32 Por. D. Maison, Jakościowe metody badań marketingowych, [w:] Badania marketingowe. Od teorii do praktyki, red. D. Maison, A. Noga-Bogomilski, Gdańsk 2007, s. 7; E. Babbie, Podstawy badań społecznych, Warszawa 2008, s. 346. 
badania nad korupcją $a^{33}$ lub agresją ${ }^{34}$. W tym przypadku technika ta posłużyła do badań stygmy społecznej.

Biorąc pod uwagę przewidywane korzyści wynikające z wykorzystania fotografii w technice wywiadu pogłębionego, zdecydowałem się na ich włączenie w strukturę scenariusza fokusowego. $Z$ powodu analogicznych względów jak w przypadku wywiadów swobodnych, także i tutaj analiza zdjęć przez uczestników odbyła się pod koniec sesji.

W wyniku analizy nagrań wideo, dokonanej pod kątem wprowadzenia materiału wizualnego, dostrzegłem, wraz ze studentami pomagającymi mi w organizacji badań, jak również odgrywającymi rolę moderatorów, prawidłowości opisane wyżej w przypadku techniki wywiadu pogłębionego (nr 2, $3,5,6,8)$ oraz inne wynikające z charakteru badań fokusowych:

1) Analiza zdjeć prowadzi do formułowania bardziej szczerych $i$ otwartych opinii wśród uczestników. Niejednokrotnie zdarzała się sytuacja, w której osoby badane, na samym początku zadania związanego z udziałem fotografii, deklarowały brak związku pomiędzy fizjonomią człowieka a jego ewentualnym przestępczym zachowaniem. Deklaracje te były składane w większości przez młode osoby. Można było jednak zaobserwować, że po chwili osoby te, obserwując pozostałych, którzy nie wyrażali sprzeciwu, aktywnie brały udział w zadaniu dokonując wskazań na podstawie fotografii. Prawidłowość tę należy wiązać ze wzajemnym wpływem uczestników, który w tym przypadku oznaczał nie tyle zmianę opinii, co zaistnienie warunków służących jej wyjawieniu.

2) Zdjęcia zachęcaty uczestników do brania udziału w dyskusji. Analiza fotografii dostarczała okazji do brania udziału w dyskusji i prezentowania swoich opinii wspieranych argumentacją. Pojawiała się ona znacznie częściej po wprowadzeniu materiału wizualnego. Uczestnicy odwoływali się do swoich osobistych doświadczeń lub opinii innych osób, starając się bronić swojego stanowiska. Zauważalny po wprowadzeniu zdjęć wzrost liczby artykułowanych przez uczestników argumentów może świadczyć o prezentowaniu przez nich opinii zgodnych z rzeczywistymi odczuciami. To z kolei daje podstawy do wiary w prawdziwość wygłaszanych sądów.

3) Analiza zdjęć sprawiała, że dyskusja obejmowała zagadnienia szczegótowe. Badani wskazując na detale widoczne na zdjęciach (ubiór, fryzura, elementy twarzy itp.) dyskutowali na temat zagadnień szczegółowych, pozwalając w sposób bezpośredni lub pośredni wnioskować o podstawach, na których

${ }^{33}$ A. Kubiak, Zastosowanie zogniskowanego wywiadu grupowego do badań nad korupcja, [w:] Zogniskowany wywiad grupowy.

${ }_{34}$ T. Pösö, P. Honkatukia, L. Nyqvist, Focus groups and the study of violence, Qualitative Research, 2008, 8. 
opierali swoją opinię. Zdjęcia dawały możliwość prowadzenia dyskusji opartej na detalach i ich roli w postrzeganiu osób, które popełniły przestępstwa.

4) Wprowadzenie zdjęć aktywizowało także tych uczestników badania, którzy do momentu analizy wizualnej pozostawali bierni. Przy realizacji niektórych sesji fokusowych zdarzało się, że grupa pozostawała dosyć bierna, zaś odpowiedzi były niezbyt wyczerpujące i udzielane jedynie przez kilka osób. Wprowadzenie elementu wizualnego, w którym każda osoba była zobowiązana do wykonania zadania, prowadziło do trwałego, a niekiedy nasilającego się wzrostu aktywności większości lub wszystkich osób biorących udział w sesji.

5) Dzięki zdjęciom dynamika działań grupy była na wysokim poziomie. Jak już wcześniej wspomniałem, analiza zdjęć powodowała szerszy udział uczestników w dyskusji, lecz także wzrost dynamiki wypowiedzi. Badani częściej artykułowali opinie, jak również częściej komentowali swoje wzajemne stanowiska, rzadziej także dochodziło do milczenia.

6) Wprowadzenie zdjęć pomogło w wizualizacji stereotypów, uprzedzeń, fobii itp. Dzięki zdjęciom udało się w dużej mierze odtworzyć fizyczne aspekty leżące u podstaw praktyk stygmatyzacyjnych. Badani odwoływali się do cech wyglądu określonych osób oraz roli, jaką one pełnią w ich postrzeganiu ludzi. Zdjęcia stanowiły naturalnie dopełnienie w analizie stereotypów w dużej mierze opartych na wrażeniach wzrokowych.

Jak już wcześniej wspomniałem, przedstawione wyżej wnioski nie wyczerpują całości omawianego zagadnienia, a jedynie stanowią zestaw wyraźnie zaobserwowanych prawidłowości, które należy jeszcze poddać dalszej weryfikacji przy odtworzeniu podobnych okoliczności badawczych.

\section{Podsumowanie}

$\mathrm{Z}$ analizy materiału empirycznego złożonego z danych uzyskanych w wyniku zastosowania techniki wywiadu pogłębionego oraz techniki zogniskowanego wywiadu grupowego wynika, że w obydwu przypadkach włączenie analizy fotografii skutkowało pozytywnymi efektami. W przypadku obu technik analiza zdjęć pozwoliła na zyskanie bardziej wartościowych i pełnych informacji, co do których istnieje zasadne przypuszczenie, że odpowiadają rzeczywistym poglądom badanych. Zdjęcia zarówno w przypadku wywiadów indywidualnych, jak i grupowych przyczyniały się do wzrostu zaangażowania uczestników badania, a w konsekwencji do udzielania także bardziej swobodnych i spontanicznych wypowiedzi. W niektórych przypadkach można było stwierdzić dwie fazy badania - przed i po wprowadzeniu analizy zdjęć. Różnica w aktywności badanych była wyraźnie dostrzegalna 
i miała bezpośredni związek z analizą materiału wizualnego. Wszystkie dotychczas przytoczone argumenty pozwalają stwierdzić, że analiza zdjęć stanowi korzystne narzędzie, podnoszące jakość technik pozyskiwania informacji wykorzystanych w badaniu. Pragnę jednak zaznaczyć, że prezentowane w niniejszym artykule wnioski mają charakter wstępny i powinny być poddane dalszej analizie w trakcie badań o tej samej lub podobnej tematyce.

\section{Dyskusja}

Przed badaczami stygmatyzacji społecznej stoi niełatwe zadanie analizowania działań aktorów społecznych, które niejednokrotnie mają charakter działań skrywanych, opartych na subtelnej grze znaczeń, które nie zawsze mogą być odczytane łatwo, a także prawidłowo. Ludzie zwykli zachowywać dla siebie swoje uprzedzenia i okoliczności, które mogą mieć na nie wpływ. Niełatwo przyznać się do oceny kogoś, z kim nie weszło się w bezpośredni kontakt, bazując jedynie na obserwacji jego wyglądu zewnętrznego. Analiza zdjęć pozwala na dogłębniejszą analizę uzyskanych danych, wzbogaconych o interpretację materiału ikonograficznego. Ponadto, jak już wcześniej zaznaczyłem, analiza zdjęć pozostaje w zgodzie z tematem badań lub nawet czyni go możliwym do eksploracji. Należy jednak pamiętać o właściwej selekcji materiałów wizualnych. Nieodpowiedni ich dobór może sprawić, że odpowiedzi badanych będą tendencyjne i oczywiste, a zatem nieprzydatne badawczo. W tym celu warto użyć metaanalizy zastosowanych technik badawczych pod kątem reakcji badanych na prezentowane zdjęcia i ich przydatności w inicjowaniu dyskusji/wypowiedzi. Krytyczna, przeprowadzona zespołowo analiza zastosowanych zdjęć daje możliwość wypracowania reguł niezbędnych w procesie dalszego doboru i selekcji materiałów wizualnych oraz opracowywania powiązanych z nimi pytań skierowanych do rozmówców.

\section{BIBLIOGRAFIA}

Aronson E., Akert R.M., Wilson T.D., Psychologia społeczna, przekł. Joanna Gilewicz, Zysk i S-ka Wydawnictwo, Warszawa 2012.

Babbie E., Podstawy badań społecznych, Wydawnictwo Naukowe PWN, Warszawa 2008.

Blumer H., Symbolic Interactionism. Perspective and Method, Prentice-Hall, Inc. Englewood Cliffs, New Jersey 1969.

Bokszański Z., Tożsamość, interakcja, grupa. Tożsamość jednostki w perspektywie teorii socjologicznej, Wydawnictwo Uniwersytetu Łódzkiego, Łódź 1989.

Chomczyński P., Problem etykietowania i stygmatyzacji wśród wychowanków zakładów poprawczych $i$ schronisk dla nieletnich. Socjologiczna analiza zjawiska, Studia Socjologiczne, 2015, $4(219)$. 
Cialdini R., Wywieranie wptywu na ludzi. Teoria i praktyka, Gdańskie Wydawnictwo Psychologiczne, Gdańsk 2009.

Daniłowicz P., Lisek-Michalska J., Fokus - zogniskowany wywiad grupowy. Zarys metody, [w:] Zogniskowany wywiad grupowy. Studia nad metoda, red. J. Lisek-Michalska, P. Daniłowicz, Wydawnictwo Uniwersytetu Łódzkiego, Łódź 2004.

Epstein I., Stevens B., McKeever P., Baruchel S., Photo elicitation interview (PEI): Using photos to elicit children's perspectives, International Journal of Qualitative Methods, 2006, 5(3), Article 1, 1-9, Retrieved [26.09.2015] from http://www.ualberta.ca/ iiqm/backissues/5_3/pdf/ epstein.pdf.

Frąckowiak M., Zdjęcie jako rebus. Zastosowanie wywiadu fotograficznego na przykładzie badań "Pornografia/erotyka: pytanie o kontekst czy estetykę?" [w:] Do zobaczenia. Socjologia wizualna w praktyce badawczej, red. J. Kaczmarek, Wydawnictwo Naukowe UAM, Poznań 2008.

Gawronski B., Rydell R.J., Vervliet B., De Houwer J., Generalization Versus Contextualization in Automatic Evaluation, Journal of Experimental Psychology: General Advance online publication, 2010 (October 4).

Goffman E., Piętno, przekł. A. Dzierżyńska, J. Tokarska-Bakir, Gdańskie Wydawnictwo Psychologiczne, Gdańsk 2005.

Harper D., Talking about pictures: a case for photo elicitation, Visual Studies, 2002, 17, 1.

Klapp O., The Fool as a Social Type, American Journal of Sociology, 1949, LV.

Konecki K.T., Ludzie i ich zwierzęta. Interakcjonistyczno-symboliczna analiza społecznego świata wtaścicieli zwierząt domowych, Wydawnictwo Naukowe Scholar, Warszawa 2005.

Konecki K.T., Wizualne wyobrażenia. Główne strategie badawcze w socjologii wizualnej a metodologia teorii ugruntowanej, Przegląd Socjologii Jakościowej, 2005, I, 1, pobrany: 07.12 2015, (http:/ / www.qualitativesociologyreview.org /PL/archive_pl.php).

Konecki K.T., Wizualna Teoria Ugruntowana. Nauczanie teorii ugruntowanej przy pomocy obrazów i analizy wizualnej, Przegląd Socjologii Jakościowej, 2010, VI, 2, pobrany: czerwiec 2011, (http:/ / www.qualitativesociologyreview.org /PL/archive_pl.php).

Kubiak A., Zastosowanie zogniskowanego wywiadu grupowego do badań nad korupcja, [w:] Zogniskowany wywiad grupowy. Studia nad metoda, red. J. Lisek-Michalska, P. Daniłowicz, Wydawnictwo Uniwersytetu Łódzkiego, Łódź 2007.

Le Dantec Ch.A., Poole E.S., The Value of Pictures: Photo Elicitation Techniques for Value Sensitive Techniques, Florence, Italy 2008 http://www.cc.gatech.edu/ ledantec/files/ledantec-poole-valueofpics-chi08.pdf, [dostęp: 30.09.2009].

Lemert E.M., Social Pathology: A Systematic Approach to the Theory of Sociopathic Behavior, McGraf-Hill, New York 1951.

Lisek-Michalska J., Badania fokusowe. Problemy metodologiczne i etyczne, Wydawnictwo Uniwersytetu Łódzkiego, Łódź 2013.

Maison D., Jakościowe metody badań marketingowych, [w:] Badania marketingowe. Od teorii do praktyki, red. D. Maison, A. Noga-Bogomilski, Gdańskie Wydawnictwo Psychologiczne, Gdańsk 2007.

Malinowski H., Komunikacja w zogniskowanym wywiadzie grupowym, [w:] Zogniskowany wywiad grupowy. Studia nad metoda, red. J. Lisek-Michalska, P. Daniłowicz, Wydawnictwo Uniwersytetu Łódzkiego, Łódź 2007.

Mead G.H., Mind Self and Society from the Standpoint of a Social Behaviorist, University of Chicago Press, Chicago 1932.

Pawłowska J., Pojęcie dewiacji w teorii etykietowania, Studia Socjologiczne, 1985, 1(96).

Pösö T., Honkatukia P., Nyqvist L., Focus groups and the study of violence, Qualitative Research, 2008, 8. 
Prus R., Grills S., The Deviant Mystique: Involvements, Realities and Regulation, Preager, The United States of America, Westport 2003.

Robertson B.J. (bez daty), Photo Elicitation: a window through which to view youth leisure in isolated communities, http://lin.ca/Uploads/cclr11/CCLR11-124.pdf, [dostęp: 30.09.2009].

Sztompka P., Socjologia wizualna. Fotografia jako metoda badawcza, Wydawnictwo Naukowe PWN, Warszawa 2005.

Welcz Z., Powstanie i rozwój teorii naznaczania społecznego, Studia Socjologiczne, 1985, 1(96). Wyka A., Badacz społeczny wobec doświadczenia, Wydawnictwo IFiS PAN, Warszawa 1993. 